\title{
The Influence Evaluation of Tourism on Chinese Rural People Living in Minority Areas
}

\author{
Cuiping Zhang1, Guangming Deng ${ }^{1,2}$, Xiaoling $\mathbf{Y u}^{1}$ \\ ${ }^{1}$ College of Science, Guilin University of Technology, Guilin, China \\ ${ }^{2}$ Guangxi Key Laboratory of Spatial Information and Geometrics, Guilin, China \\ Email: 670553212@qq.com
}

Received 27 February 2014; revised 27 March 2014; accepted 3 April 2014

Copyright @ 2014 by authors and Scientific Research Publishing Inc.

This work is licensed under the Creative Commons Attribution International License (CC BY). http://creativecommons.org/licenses/by/4.0/

(c) (;) Open Access

\begin{abstract}
In this paper, through understanding the basic situation of three villages at different stages of life cycle development about tourism, using the method of grey correlation analysis from the quantitative aspects, the results show that impact assessment on rural tourism in different stages is different [1]. The impact on tourism stable stage is the most; tourism decline stage is relatively weak; tourism development stage is the weakest.
\end{abstract}

\section{Keywords}

\section{Chinese Rural Tourism, Grey Relational Analysis, Effect Evaluation}

\section{Introduction}

Tourism is the sum of the activities and phenomena that people leave the place of residence to another place to visit, tour etc. [2]. Tourism is an association process of tourists and tour scenic area residents. It will produce the effect in certain economic, transportation, social cultural and natural environment on scenic area surrounding residents living [3]. And the different stages of tourism influence are also different [4]. This paper quantitatively analyzes that the effects of different stages of tourism on rural life are also different [5].

\section{Gray Correlation Method}

Grey correlation analysis [6] is an important method to investigate the association degree in grey system theory. The main idea of it is: between factors, many objects, the relationship Is more complex, people in the under- 
standing, analysis, decision-making, not comprehensive, sufficient information, not easy to form a clear concept. The evaluation factors are not completely known relationship between albino, has obvious advantage in small sample system theory analysis of imprecise information, do not completely determine. Evaluation of tourism impact on three ethnic areas is affected by many factors, there are subjective views of some assessment on all rural residents, and the links between the various factors is not completely known, that is to say the impact of tourism on the rural life of three ethnic minority areas with grey [7]. So the study, through the gray correlation analysis were used to study the effects of tourism on the rural life of three ethnic minority areas. Analysis of the specific steps are as follows.

\subsection{Determine the Comparison Sequence and the Standard Sequence}

Set the evaluation object is $m$, the evaluation index of $n$, the standard data column is $x_{0}$, the $k$ index value is denoted as $x_{0}(k)$, standard data list formula:

$$
x(0)=\left\{x_{0}(k)\right\}, k=1,2,3, \cdots, n
$$

Comparative data column is a column object data research, said formula:

$$
x_{i}=\left\{x_{i}(k), k=1,2,3, \cdots, n\right\}, i=1,2,3, \cdots, m
$$

\subsection{To Determine the Index Value of the Corresponding Weight $w_{k}$}

The factor analysis method in the analysis to determine the weight of indicators by principal component analysis. Where $w_{k}$ is the weight of the first $k$ evaluation indexes.

$$
w=\left\{w_{k}, k=1,2,3, \cdots, n\right\}
$$

\subsection{The Gray Relational Coefficient Calculation}

In the analysis of standard data column and compare data correlation column, first of all, to analyze the correlation degree of each index, with the correlation coefficient to express:

$$
\xi_{t}(k)=\frac{\partial_{\min }+\rho \cdot \partial_{\max }}{\partial_{t}(\kappa)+\rho \cdot \partial_{\max }}
$$

where $\xi_{l}(k)$ is the relative difference that the comparison of series $x_{i}$ and Series $x_{0}$ in the $k$ evaluation standard, known as the $x_{i}$ of $x_{0}$ in $k$ moment correlation coefficient; $\partial_{\min }$ is the two smallest difference; $\partial_{\max }$ is the two biggest difference; $\partial_{l}(\kappa)=\left|x_{o}(\kappa)-x_{i}(\kappa)\right| ; \rho$ is the distinguishing coefficient, and $0<\rho \leq 1$, this paper takes a value of 0.5 . (The value of $\rho$ has a great influence on the correlation coefficient, Professor of general Deng Julong founded the grey model when the value is $\rho=0.5$.)

\subsection{The Calculation of Grey Relational Degree}

Correlation is a measure of correlation among things, factors, by the correlation coefficient needs to be evolved, correlation coefficient of each index by integrating the relationship for a comprehensive value, namely the correlation $\left(r_{i}\right)$ :

$$
r_{i}=\frac{1}{n} \sum_{k=1}^{n} w_{k} \xi_{i}(k)
$$

$r_{i}$ is the degree of Association of standard data columns $x_{0}$ and compares the data column $x_{i}$.

\subsection{According to the Degree of Association, Establish Relational Order of Evaluation Objects}

Relational $r_{i}$ is close to degree of standard data columns and compares the data column. According to the size of the correlation, sort of each evaluation object, establish the relational order of evaluation object. 


\section{Analysis of the Impact of Tourism on Rural Life in Minority Areas}

\subsection{Determine the Comparison Sequence and the Standard Sequence}

In this paper, the impacts of tourism on rural life data taken from the literature [8]. Because the data is obtained by questionnaire, and every problems with the Likert five point scale [9] from " 1 strongly disagree" to " 5 very much agree with" do score process an as the comparative sequence. Secondly, since there is no absolute evaluation of various indicators of impact of tourism on three national area value than other ethnic areas in the condition of high values of evaluation indexes, Therefore, we selected the evaluation index of each index's biggest series as standard series, the data in Table 1 .

\subsection{Analysis to Determine the Weights of Evaluation Indexes by Using the Principal Component $w_{k}$}

The principal component analysis method is based on acquiring all the index test data, using statistical methods to analyze the relative importance factor index, obtained through the shaft. Each factor's contribution rate and accumulated contribution rate will compared, as the weight of the factor ratio. Since tourism plays an important role in politics, economy, environment, culture, the four level two indexes, the weights of four two level index set equivalent. It can not only reflect the travel and Have equal importance on the influence between the four, and three valuation results can provide good solutions to the coordinated development between tourism and ethnic minority areas. The weight of each index such as last table quoted data document.

\subsection{The Gray Relational Coefficient Calculation}

Table 1 is normalized, the method is to use a maximum value of 10 to remove all the Evaluation index table score standard series, Expressed as a percentage of tourism on the impact of various ethnic minority areas,

Table 1. Scores of the index of evaluation about the tourism impact on three minority areas and standard data column.

\begin{tabular}{|c|c|c|c|c|c|}
\hline Two levels of index & Three levels of index & $\begin{array}{l}\text { Development stage } \\
\text { Xijiang Miao Village }\end{array}$ & $\begin{array}{l}\text { The stable stage } \\
\text { Hongyan Village }\end{array}$ & $\begin{array}{l}\text { Decline stage } \\
\text { Butterfly Valley }\end{array}$ & $\begin{array}{l}\text { Standard data } \\
\text { columns }\end{array}$ \\
\hline \multirow{3}{*}{$\begin{array}{l}\text { Political influence } \\
\text { evaluation index }\end{array}$} & Cadre corruption & 4.12 & 8.03 & 6.40 & 8.03 \\
\hline & Policy changes & 7.35 & 7.35 & 7.98 & 7.98 \\
\hline & Understand policy & 7.39 & 8.39 & 7.72 & 8.39 \\
\hline \multirow{4}{*}{$\begin{array}{l}\text { Economic impact } \\
\text { evaluation index }\end{array}$} & Poverty gap & 8.30 & 6.54 & 5.51 & 8.30 \\
\hline & Rent prices & 7.35 & 6.56 & 7.55 & 7.55 \\
\hline & The land problem & 7.41 & 7.09 & 6.78 & 7.41 \\
\hline & To increase the income of farmers & 6.25 & 7.90 & 8.38 & 8.38 \\
\hline \multirow{4}{*}{$\begin{array}{l}\text { Environmental impact } \\
\text { evaluation index }\end{array}$} & Sanitary conditions & 9.54 & 9.93 & 9.96 & 9.96 \\
\hline & Infrastructure & 9.91 & 9.94 & 10.0 & 10.0 \\
\hline & Traffic jam & 6.22 & 8.63 & 8.90 & 8.90 \\
\hline & The ecological environment & 8.48 & 9.79 & 8.29 & 9.79 \\
\hline \multirow{8}{*}{$\begin{array}{l}\text { Cultural impact } \\
\text { evaluation index }\end{array}$} & Outdated customs and bad habits & 7.86 & 8.26 & 8.45 & 8.45 \\
\hline & External conflict & 6.71 & 8.80 & 7.70 & 8.80 \\
\hline & Family and marriage & 6.89 & 9.11 & 7.29 & 9.11 \\
\hline & Religious conflict & 8.44 & 8.70 & 8.46 & 8.70 \\
\hline & The crime rate & 7.04 & 9.82 & 7.37 & 9.82 \\
\hline & Technology information & 7.42 & 8.60 & 7.64 & 8.60 \\
\hline & Neighborhood disputes & 6.17 & 8.00 & 9.34 & 9.34 \\
\hline & Moral standards & 8.02 & 8.08 & 8.91 & 8.91 \\
\hline
\end{tabular}


processing are presented in Table 2.

According to Table 2 provides data can get two level minimum difference $\partial_{\min }=0$ and level two maximum difference $\partial_{\max }=58.8$. Then, calculate the standard data column and compare data column of the absolute difference, standard data are presented and compared the data column absolute difference is shown in Table 3.

Now known to two level minimum difference, two level maximum difference and absolute difference, using the grey coefficient model of grey correlation coefficient in Table 4.

\subsection{Calculation of Impact of Tourism on Three Ethnic Areas of Grey Correlation Degree, Establish the Correlation Sequence}

According to the calculation model of grey correlation degree, result show that various indices affecting tourism three ethnic areas of grey correlation degree and correlation size, see Table 5.

\subsection{According to the Degree of Association, Establish Relational Order of Evaluation Objects}

From the impact of tourism on the three minority area the size of the gray relational grade can be seen, the greatest impact on the stable stage of tourism Hongyan village, grey correlation degree is 0.051942 ; the decline of the Butterfly Valley stage effects, grey correlation degree is 0.051219; effect on the stage of development of Qianhu Miao Village of the minimum, the grey correlation value 0.050423 .

$$
\text { As: } \quad r_{\text {stable }}>r_{\text {decline }}>r_{\text {development }}
$$

Table 5 shows:

\section{- Tourism has grade of three ethnic minority areas}

Grey correlation of tourism on the steady stage Hongyan village value is 0.051942 , is the three research in

Table 2. The degree of tourism influence on three minority areas.

\begin{tabular}{|c|c|c|c|c|}
\hline Two levels of index & Three levels of index & $\begin{array}{c}\text { Development stage } \\
\text { Xijiang MiaoVillage (\%) }\end{array}$ & $\begin{array}{c}\text { The stable stage } \\
\text { Hongyan Village (\%) }\end{array}$ & $\begin{array}{c}\text { Decline stage } \\
\text { Butterfly Valley (\%) }\end{array}$ \\
\hline \multirow{3}{*}{$\begin{array}{l}\text { Political influence } \\
\text { evaluation index }\end{array}$} & Cadre corruption & 41.2 & 80.3 & 64.0 \\
\hline & Policy changes & 73.5 & 73.5 & 79.8 \\
\hline & Understand policy & 73.9 & 83.9 & 77.2 \\
\hline \multirow{4}{*}{$\begin{array}{l}\text { Economic impact } \\
\text { evaluation index }\end{array}$} & Poverty gap & 83.0 & 65.4 & 55.1 \\
\hline & Rent prices & 73.5 & 65.6 & 75.5 \\
\hline & The land problem & 74.1 & 70.9 & 67.8 \\
\hline & To increase the income of farmers & 62.5 & 79.0 & 83.8 \\
\hline \multirow{4}{*}{$\begin{array}{l}\text { Environmental impact } \\
\text { evaluation index }\end{array}$} & Sanitary conditions & 95.4 & 99.3 & 99.6 \\
\hline & Infrastructure & 99.1 & 99.4 & 100.0 \\
\hline & Traffic jam & 62.2 & 86.3 & 89.0 \\
\hline & The ecological environment & 84.8 & 97.9 & 82.9 \\
\hline \multirow{8}{*}{$\begin{array}{l}\text { Cultural impact } \\
\text { evaluation index }\end{array}$} & Outdated customs and bad habits & 78.6 & 82.6 & 84.5 \\
\hline & External conflict & 67.1 & 88.0 & 77.0 \\
\hline & Family and marriage & 68.9 & 91.1 & 72.9 \\
\hline & Religious conflict & 84.4 & 87.0 & 84.6 \\
\hline & The crime rate & 70.4 & 98.2 & 73.7 \\
\hline & Technology information & 74.2 & 86.0 & 76.4 \\
\hline & Neighborhood disputes & 61.7 & 80.0 & 93.4 \\
\hline & Moral standards & 80.2 & 80.8 & 89.1 \\
\hline
\end{tabular}


Table 3. The absolute difference of standard data column and compared data column.

\begin{tabular}{|c|c|c|c|c|}
\hline Two levels of index & Three levels of index & $\begin{array}{c}\text { Development stage } \\
\text { Xijiang Miao Village (\%) }\end{array}$ & $\begin{array}{l}\text { The stable stage } \\
\text { Hongyan Village (\%) }\end{array}$ & $\begin{array}{c}\text { Decline stage } \\
\text { Butterfly Valley (\%) }\end{array}$ \\
\hline \multirow{3}{*}{$\begin{array}{l}\text { Political influence } \\
\text { evaluation index }\end{array}$} & Cadre corruption & 39.10 & 0.00 & 16.30 \\
\hline & Policy changes & 6.30 & 6.30 & 0.00 \\
\hline & Understand policy & 10.00 & 0.00 & 6.70 \\
\hline \multirow{4}{*}{$\begin{array}{l}\text { Economic impact } \\
\text { evaluation index }\end{array}$} & Poverty gap & 0.00 & 17.60 & 27.90 \\
\hline & Rent prices & 2.00 & 9.90 & 0.00 \\
\hline & The land problem & 0.00 & 3.20 & 6.30 \\
\hline & To increase the income of farmers & 21.30 & 4.80 & 0.00 \\
\hline \multirow{4}{*}{$\begin{array}{l}\text { Environmental impact } \\
\text { evaluation index }\end{array}$} & Sanitary conditions & 4.20 & 0.30 & 0.00 \\
\hline & Infrastructure & 0.90 & 0.60 & 0.00 \\
\hline & Traffic jam & 26.80 & 2.70 & 0.00 \\
\hline & The ecological environment & 13.10 & 0.00 & 15.00 \\
\hline \multirow{8}{*}{$\begin{array}{l}\text { Cultural impact } \\
\text { evaluation index }\end{array}$} & Outdated customs and bad habits & 5.90 & 1.90 & 0.00 \\
\hline & External conflict & 20.90 & 0.00 & 11.00 \\
\hline & Family and marriage & 22.20 & 0.00 & 18.20 \\
\hline & Religious conflict & 2.60 & 0.00 & 2.40 \\
\hline & The crime rate & 27.80 & 0.00 & 24.50 \\
\hline & Technology information & 11.80 & 0.00 & 9.60 \\
\hline & Neighborhood disputes & 31.70 & 13.40 & 0.00 \\
\hline & Moral standards & 8.90 & 8.30 & 0.00 \\
\hline
\end{tabular}

Table 4. Grey relevant coefficient of the tourism impact on three minority areas.

\begin{tabular}{|c|c|c|c|c|}
\hline Two levels of index & Three levels of index & $\begin{array}{l}\text { Development stage } \\
\text { Xijiang Miao Village }\end{array}$ & $\begin{array}{l}\text { The stable stage } \\
\text { Hongyan Village }\end{array}$ & $\begin{array}{l}\text { Decline stage } \\
\text { Butterfly Valley }\end{array}$ \\
\hline \multirow{3}{*}{$\begin{array}{l}\text { Political influence } \\
\text { evaluation index }\end{array}$} & Cadre corruption & 0.883 & 1.000 & 0.947 \\
\hline & Policy changes & 0.979 & 0.979 & 1.000 \\
\hline & Understand policy & 0.967 & 1.000 & 0.978 \\
\hline \multirow{4}{*}{$\begin{array}{l}\text { Economic impact } \\
\text { evaluation index }\end{array}$} & Poverty gap & 1.000 & 0.944 & 0.913 \\
\hline & Rent prices & 0.993 & 0.967 & 1.000 \\
\hline & The land problem & 1.000 & 0.989 & 0.979 \\
\hline & To increase the income of farmers & 0.932 & 0.984 & 1.000 \\
\hline \multirow{4}{*}{$\begin{array}{l}\text { Environmental impact } \\
\text { evaluation index }\end{array}$} & Sanitary conditions & 0.986 & 0.999 & 1.000 \\
\hline & Infrastructure & 0.997 & 0.998 & 1.000 \\
\hline & Traffic jam & 0.916 & 0.991 & 1.000 \\
\hline & The ecological environment & 0.957 & 1.000 & 0.951 \\
\hline \multirow{8}{*}{$\begin{array}{l}\text { Cultural impact } \\
\text { evaluation index }\end{array}$} & Outdated customs and bad habits & 0.980 & 0.994 & 1.000 \\
\hline & External conflict & 0.934 & 1.000 & 0.964 \\
\hline & Family and marriage & 0.930 & 1.000 & 0.942 \\
\hline & Religious conflict & 0.991 & 1.000 & 0.992 \\
\hline & The crime rate & 0.914 & 1.000 & 0.923 \\
\hline & Technology information & 0.961 & 1.000 & 0.968 \\
\hline & Neighborhood disputes & 0.903 & 0.956 & 1.000 \\
\hline & Moral standards & 0.971 & 0.973 & 1.000 \\
\hline
\end{tabular}


Table 5. Grey correlation degree of the tourism impact on three minority areas.

\begin{tabular}{|c|c|c|c|c|}
\hline Two levels of index & Three levels of index & $\begin{array}{l}\text { Development stage } \\
\text { Xijiang Miao Village }\end{array}$ & $\begin{array}{l}\text { The stable stage } \\
\text { Hongyan Village }\end{array}$ & $\begin{array}{l}\text { Decline stage } \\
\text { Butterfly Valley }\end{array}$ \\
\hline \multirow{3}{*}{$\begin{array}{l}\text { Political influence } \\
\text { evaluation index }\end{array}$} & Cadre corruption & 0.006191 & 0.007012 & 0.00664 \\
\hline & Policy changes & 0.003781 & 0.003781 & 0.003862 \\
\hline & Understand policy & 0.002209 & 0.002284 & 0.002234 \\
\hline \multirow{4}{*}{$\begin{array}{l}\text { Economic impact } \\
\text { evaluation index }\end{array}$} & Poverty gap & 0.005401 & 0.005099 & 0.004931 \\
\hline & Rent prices & 0.003340 & 0.003252 & 0.003363 \\
\hline & The land problem & 0.002442 & 0.002415 & 0.002391 \\
\hline & To increase the income of farmers & 0.001819 & 0.00192 & 0.001951 \\
\hline \multirow{4}{*}{$\begin{array}{l}\text { Environmental impact } \\
\text { evaluation index }\end{array}$} & Sanitary conditions & 0.004078 & 0.004131 & 0.004136 \\
\hline & Infrastructure & 0.003566 & 0.003569 & 0.003576 \\
\hline & Traffic jam & 0.0026 & 0.002813 & 0.002838 \\
\hline & The ecological environment & 0.002496 & 0.002608 & 0.00248 \\
\hline \multirow{9}{*}{$\begin{array}{l}\text { Cultural impact } \\
\text { evaluation index }\end{array}$} & Outdated customs and bad habits & 0.002567 & 0.002604 & 0.002620 \\
\hline & External conflict & 0.001981 & 0.002121 & 0.002045 \\
\hline & Family and marriage & 0.001661 & 0.001786 & 0.001682 \\
\hline & Religious conflict & 0.001441 & 0.001454 & 0.001442 \\
\hline & The crime rate & 0.00128 & 0.0014 & 0.001292 \\
\hline & Technology information & 0.00132 & 0.001374 & 0.00133 \\
\hline & Neighborhood disputes & 0.001113 & 0.001179 & 0.001233 \\
\hline & Moral standards & 0.001138 & 0.001141 & 0.001172 \\
\hline & $r_{i}$ & 0.050423 & 0.051942 & 0.051219 \\
\hline
\end{tabular}

minority regions most affected. This is because of its popularity, publicity, scenic facilities, has formed the characteristics are most consistent with the tourist place, therefore, rural residents in minority areas of the various indicators of evaluation of the effects of perception are more obvious, the evaluation result is the highest.

Tourism on the effects of fading Butterfly Valley stage second, association degree has reached 0.051219. This is because the ethnic area after a long time after the destruction of tourism, more of the surrounding ecological environment, coupled with the visitors seldom go reasons, so each index of perception of the impact assessment phase fading Butterfly Valley residents are obvious. The impact of tourism on the development stage of Qianhu Miao Village minimum, grey correlation degree is 0.050423 , the last in the three evaluation areas. This is because the Qianhu Miao village is still in the stage of tourism development, facilities imperfect, national characteristics are not fully displayed and visibility and other reasons are not mature, so the travel to also have certain effect, but and other two ethnic groups influence overall relatively weak.

\section{- Impact of tourism on three national area attenuation in development}

Tourism to the strength attenuation law in the development of ethnic minority areas with three shadow, especially economic impact Strength is very strong, rural residents benefit And National are a travel stage has significant positive correlation. The biggest benefit is the stable stage of rural residents, followed by rural residents, the development stage of rural residents.

\section{Summary}

Sustainable development is the theme of tourism development [10]. Sustainable development emphasizes that rural residents participation in tourism and control tourism benefit. At the same time the ethnic area is the comprehensive function of sustainable development, also can grasp the entity, and is a feasible approach from the perspective of rural tourism [11]. 
The impact of tourism is especially outstanding in the minority areas. From the perspective of rural residents we study the influence of tourism on rural that will have an important significance to the development and construction of the country or regions, and the local government and tourism developers is important.

\section{References}

[1] Liu, T. and Xu, F.Y. (2010) The Rural Community Participation in Tourism in the Interest Conflict and Coordination. Social Scientists, 1, 91-94.

[2] Liu, Y. (2007) Case of Ethnic Communities Social Impact of Rural Tourism in Sichuan Jiaju Tibetan Area Survey. Ningxia Social Science, 1, 77-79.

[3] Zhang, H. and Gong, S. (2008) Study on Effect of Rural Tourism Development in the Construction of Harmonious Jiangxi and Countermeasures. Network Wealth, 1, 91-93.

[4] Wang, J.N. (2010) Impact of Rural Tourism on the Rural Community. Zhejiang University, Hangzhou.

[5] Rong, C. (2011) The Influence of the Development of Rural Tourism on the Rural Economy. Modern Economic Information, 1, 243.

[6] Deng, J.L. (1992) Grey System Method. Huazhong University of Science and Technology Press, Wuhan.

[7] Deng, N.M. (2005) Analysis of Hotel Customer Satisfaction Grey. Technology and Management, 5.

[8] Zhang, C.P., Deng, G.M. and Yu, X.L. (2013) The Influence of Tourism on Rural Life in Minority Areas. Applied Mathematics, 4, 1207-1211. http://dx.doi.org/10.4236/am.2013.48162

[9] Ap, J. (1992) Residents’ Perceptions on Tourism Impacts. Annals of Tourism Research, 19, 665-690. http://dx.doi.org/10.1016/0160-7383(92)90060-3

[10] Zhang, X.M. (2011) In the Construction of Harmonious Society of Social Contradictions to Resolve. Anhui University, Hefei.

[11] Xie, Y.J. (2001) Reflections on Chinese Tourism Planning Problem. Journal of Dongbei University of Finance and Economics, 4, 40-42. 